\title{
SUPEROKSIDA DISMUTASE (SOD) DAN RADIKAL BEBAS
}

\author{
Evirosa Simanjuntak ${ }^{1}$, Zulham ${ }^{2}$ \\ ${ }^{1}$ Fakultas Kedokteran Methodist Indonesia \\ Jl. Setia Budi Pasar II Tanjung Sari, Medan 20132 \\ 2 Fakultas Kedokteran Universitas Sumatera Utara \\ e-mail : evirosadr@yahoo.com
}

DOI : https://doi.org/10.35451/jkf.v2i2.342

\begin{abstract}
Superoxide dismutase (SOD) is an endogenous antioxidant that works by regulating ROS levels. This group of enzymes functions to catalyze the efficient disposal of superoxide anions. Superoxide anions are produced enzymatically and non-enzymatically. In mammals there are 3 types of SOD, namely SOD1 (CuZnSOD), SOD2 (MnSOD), SOD3 (ECSOD). Oxidative stress caused by free radicals has been reported to be involved in several diseases. Various stressors trigger ROS production, also triggering the production of enzymatic antioxidants such as catalase $(C A T)$, hydroperoxidase $(H P x)$, and superoxide dismutase (SOD). Free radicals cause oxidative stress when the amount in the body is excessive, this situation will cause oxidative damage at the cellular, tissue to organ levels that will accelerate the aging process and the onset of disease. Free radicals are molecules that have one or more unpaired electrons and are therefore relatively unstable. Free radicals try to stabilize themselves by taking electrons from other molecules and will produce reactive oxygen species (ROS). If there is a disturbance in the balance of ROS products with antioxidants, oxidative stress will occur which results in damage to cell components. The higher levels of oxidative stress will increase the lipid peroxidation marker which is presented as malondialdehyde (MDA) and decrease the SOD enzyme activity. Thus the role of molecules that have antioxidant activity is very necessary to ward off oxidative stress.
\end{abstract}

Keywords: superoksida dismutase, radikal bebas, stress oksidatif,antioksidan

\section{PENDAhUluan}

Seiring dengan perkembangan waktu, pola kehidupan manusiapun banyak berubah. Perubahan ini mengakibatkan tubuh manusia sering terpapar zat-zat berbahya yang dapat menyebabkan penyakit dan perubahan degeneratif. Dan sebagian besar penyakit diawali dengan terjadinya reaksi oksidasi yang berlebihan di dalam tubuh manusia (Euis, 2018)
Radikal bebas memiliki peranan yang penting dalam kondisi fisiologis dan pengaruhnya dalam berbagai penyakit. Radikal bebas berasal dari luar tubuh (sumber eksogen) maupun dari dalam tubuh (sumber endogen). Sumber eksogen berupa polusi, alkohol, asap tembakau, logam berat, logam transisi, pelarut industri, pestisida, obat-obatan tertentu seperti halotan, parasetamol, dan radiasi. Sedangkan sumber endogen adalah mitokondria, peroksisom, retikulum 
endoplasma, sel fagositik dan lainnya (Phaniendra, Jestadi, \& Periyasamy, 2015).

Radikal bebas adalah suatu hasil samping proses metabolisme normal yang disebut Reactive Oxygen Species (ROS) dan senyawa nitrogen reaktif (SNR) yang terintegrasi (Winarsih, 2007). Produksi ROS dapat mengganggu homeostasis atau menstimulasi pertumbuhan sel, tergantung pada besarnya jumlah ROS yang diproduksi dalam tubuh kita. Tetapi bila produksi ROS melebihi kapasitas antioksidan, akan mengarahkan sel menuju stres oxidatif (Widayati, 2012).

Radikal bebas mengandung elektron yang tidak berpasangan pada kulit terluar sehingga mampu untuk menarik elektron dari molekul di sekelilingnya dengan sangat reaktif untuk melengkapi kekurangan elektron di dalamnya. Sebagai akibatnya, molekul yang kehilangan elektron akan berubah menjadi radikal yang baru dan akhirnya menyebabkan kerusakan sel, gangguan fungsi sel, bahkan kematian sel. (Krajcovicova-Kudlackova et al., 2006).

Radikal bebas akan mengakibatkan terjadinya stres oksidatif bila jumlahnya dalam tubuh berlebih, keadaan ini akan menyebabkan terjadinya kerusakan oksidatif pada tingkat sel, jaringan hingga organ tubuh yang akan mempercepat terjadinaya proses penuaan dan timbulnya penyakit (Euis, 2018). Stres oksidatif yang terjadi akibat radikal bebas dilaporkan terlibat dalam timbulnya beberapa penyakit seperti : diabetes mellitus, kelainan neurodegeneratif (penyakit Parkinson, penyakit Alzheimer dan Multiple sclerosis), penyakit kardiovaskular (aterosklerosis dan hipertensi), penyakit saluran pernapasan (asma), katarak, rheumatoid arthritis dan berbagai keganasan (kanker kolorektal, kanker prostat, kanker payudara, kanker paru dan kanker kandung kemih) (Phaniendra et al., 2015).

Berbagai stressor selain memicu produksi ROS, juga memicu produksi antioksidant enzymatik seperti catalase (CAT), hydroperoksidase (HPx) dan superoksida dismutase (SOD) (Izyumov et al., 2010; Widayati, 2012). Antioksidan dapat mencegah terjadinya stres oksidatif dengan cara menghambat oksidasi molekul (Ardhie, 2011). Sel tubuh kita menyediakan antioksidan enzimatis maupun nonenzimatis untuk menetralkan ROS (Widayati, 2012). Enzim superoxide dismutase (SOD) adalah suatu antioksidan endogen yang bekerja dengan cara mengatur kadar ROS (Landis \& Tower, 2005; Younus, 2018). Dengan demikian peran molekul yang memiliki aktivitas sebagai antioksidan sangat diperlukan untuk menangkal stress oksidatif (Tan, Norhaizan, Liew, \& Rahman, 2018).

Superoksida dismutase (SOD) ditemukan pada tahun 1969. Selama 5 dekade terakhir beberapa penelitian telah dilakukan pada berbagai spesies seperti bakteri dan mamalia.. Pada manusia juga telah dipelajari mengenai kelas enzim ini dan diperkirakan bahwa enzim-enzim ini telah ada sejak lama, dan kemungkinan beberapa enzim asli yang ditemukan ada dalam kehidupan primitif. Lalu kehidupan berevolusi, dan diduga enzim-enzim ini telah memiliki peran fungsional baru (Case, 2017).

\section{TINJAUAN PUSTAKA}

\section{Radikal Bebas}

Radikal bebas merupakan molekul yang relative tidak stabil. Untuk memperoleh kestabilannya, maka molekul yang bersifat reaktif tersebut akan mencari pasangan elektronnya, sehingga disebut juga 
sebagai reactive oxygen species (ROS). Mekanismenya terjadi melalui donasi ataupun dengan mengambil dari sel tubuh lain (Ardhie, 2011; Masaki, 2010). Radikal bebas berusaha menstabilkan diri dengan mengambil elektron dari molekul lain. Dalam keadaan normal, pembentukan ROS dan aktivitas antioksidan seimbang di dalam sel. Apabila terjadi gangguan terhadap keseimbangan tersebut maka akan terjadi stress oksidatif yang mengakibatkan kerusakan komponen komponen sel (Bag \& Bag, 2008; Fahn et al., 1998; Harju et al., 2004; Zainuri \& Wanandi, 2012). Molekul penting di dalam tubuh yang rentan dirusak oleh radikal bebas yaitu deoxyribonucleic acid (DNA), lemak, dan protein (Krajcovicova-Kudlackova et al., 2006).

Terjadinya oksidasi terhadap koenzim flavin tereduksi di dalam mitokondria dan rangkaian transpor elektron dalam mikrosom berlangsung melalui proses stabilisasi radikal flavin semiquanon oleh protein pengikat, dan selanjutnya akan membentuk radikal oksigen (superoksida) sebagai hasil sementara atau sampingan (Widayati, 2012).

Pembentukan radikal bebas selama proses pernafasan dan metabolisme akan mengakibatkan kerusakan endotel dan terjadinya mutasi DNA. Hal ini selanjutnya mengakibatkan timbulnya berbagai penyakit (Fachir \& Setiawan, 2005). Radikal bebas akan menyerang makromolekul penting dalam tubuh yang kemudian akan menyebabkan kerusakan sel dan gangguan homeostatis. Sasaran radikal bebas meliputi semua jenis molekul dalam tubuh yaitu lipid, asam nukleat, dan protein adalah target utama (Lobo, Patil, Phatak, \& Chandra, 2010)

\section{Antioksidan}

Antioksidan diperlukan untuk mencegah terjadinya stres oksidatif yang merupakan penyebab terjadinya penyakit. Antioksidan endogen diperlukan dalam mekanisme perlawanan tubuh terhadap stres oksidatif. Tetapi bila jumlah radikal bebas dan spesies reaktif di dalam tubuh kita melebihi kapasitas antioksidan endogen, maka tubuh kita akan memerlukan asupan antioksidan eksogen yang diperoleh dari makanan atau obat-obatan (Werdhasari, 2014). Stress oksidatif yang terjadi karena ketidakseimbangan prooksidan (produksi ROS) dan antioksidan mengakibatkan kerusakan molekuler dan seluler. Stres oksidatif berperanan penting dalam perkembangan penyakit. Antioksidan dapat mengendalikan autoksidasi dengan menghambat pembentukan radikal bebas dan selanjutnya mengurani stress oksidatif (Tan et al., 2018; Winarsi, Wijayanti, \& Purwanto, 2012).

\section{Superoksida dismutase (SOD)}

Superoksida dismutase (SOD) adalah kelompok enzim yang berfungsi mengkatalisasi pembuangan anion superoksida secara efisien (Zelko, Mariani, \& Folz, 2002). Anion superoksida dihasilkan secara enzimatik dalam sistem xanthinexanthine oksidase dan non-enzimatik dalam sistem phenazine methosulphate-NADH, dan diuji dengan reduksi nitro blue tetrazolium (Robak \& Gryglewski, 1988). Pemeriksaan sejarah evolusi enzim memberikan penjelasan lebih lanjut mengenai peran SOD modern dalam fisiologi dan penyakitHal ini menjelaskan tentang reaksi molekuler, subseluler, lokasi dan spesifik isoform SOD (Case, 2017).

Hingga saat ini berdasarkan aspek biokimia dan molekuler pada mamalia terdapat 3 jenis superoksida dismutase yaitu SOD1, SOD2 dan SOD 
3 (S. H. Kim et al., 2014; Zelko et al., 2002). Senyawa SOD 1 atau CuZnSOD merupakan enzim pertama yang dikarakteristik dan merupakan homodimer yang mengandung tembaga dan seng. Ditemukan pada sitoplasma intraseluler (Zelko et al., 2002). Senyawa ini telah lama dikenal sebahai antioksidan yang berfungsi untuk mengkatalisis superoksida menjadi hidrogen peroksida. Saat ini telah dilaporkan bahwa SOD 1 berperan dalam pensinyalan oksidatif : sebagai respon terhadap peningkatan ROS, dimana SOD 1 akan cepat berpindah ke dalam nukleus untuk menjaga stabilitas genom (Tsang, Liu, Thomas, Zhang, \& Zheng, 2014). Senyawa SOD2 atau MnSOD merupakan tetramer yang disintesis dan mengandung mangan. Enzim ini berada di dalam mitokondria (Zelko et al., 2002). Enzim MnSOD adalah antioksidan endogen yang dapat menangkap dan menguraikan radikal bebas di dalam sel menjadi zat yang kurang reaktif. Stres oksidatif menyebabkan kerusakan oksidatif lipid yang dapat dideteksi dengan peningkatan kadar Malondialdehyde (MDA) dalam sel (Zainuri \& Wanandi, 2012). Senyawa SOD3 atau ECSOD adalah tetramer yang mengandung tembaga dan seng. Dan disintesis mengandung peptida sinyal untuk mengarahkannya ke ruang ekstraseluler (Zelko et al., 2002; Zhang et al., 2012). Peranan SOD 3 adalah bekerja pada permukaan sel untuk melindungi sel dari stress oksidatif (J. Kim et al., 2014).

Stres oksidatif yang meningkat akibat hipoksia yang kronis terjadi karena produksi ROS yang berlebihan tanpa adanya kompensasi aktivitas enzim antioksidan (Pialoux et al., 2009). Dan beberapa penelitian telah membuktikan bahwa selama terjadinya hipoksia maka produksi ROS akan meningkat sehingga menekan aktivitas enzim SOD. Karena hipoksia merupakan pemicu terjadinya inhibisi parsial aktivitas rantai transport electron akibat dari bocornya electron sehingga terbentuklah ROS (Winarsi et al., 2012). Selama terjadinya siklus hipoksia, ROS akan terbentuk secara enzimatis melalui jalur xantin oksidase. Hal ini dapat mengakibatkan stres oksidatif semakin tinggi sehingga sehingga berdampak pada penurunan aktivitas enzim SOD (Winarsi et al., 2012; Yuan et al., 2004). Beberapa studi mengatakan bahwa semakin tinggi kadar stress oksidatif akan meningkatkan marker peroksidasi lipid yang dipresentasikan sebagai malondialdehida (MDA) dan menurunkan aktivitas enzim SOD (Abramov, Scorziello, \& Duchen, 2007; Winarsi et al., 2012). Malondialdehid merupakan senyawa toksik yang dapat mengganggu keutuhan membran sel, karena itu bila kadarnya tidak segera diturunkan, maka akan mengganggu berfungsinya sel (Winarsi et al., 2012). Terjadinya hipoksia sistemik menyebabkan kerusakan oksidatif pada sel hati yang ditandai dengan meningkatnya kadar MDA disertai respon penurunan aktivitas antioksidan MnSOD dan katalase (Zainuri \& Wanandi, 2012).

\section{KESIMPULAN}

1. Superoksida dismutase (SOD) adalah enzim yang berfungsi mengkatalisasi pembuangan anion superoksida secara efisien dan merupakan antioksidan endogen.

2. Pada mamalia terdapat 3 jenis superoksida dismutase yaitu SOD1 (CuSOD) terdapat di dalam sitoplasma, SOD2 (MnSOD) terdapat di dalam mitokondria dan SOD 3 
(ECSOD) berada dalam ekstraseluer.

3. Stres oksidatif terjadi akibat radikal bebas dan mengakibatkan timbulnya beberapa penyakit.

4. Antioksidan berperan menghambat pembentukan radikal bebas dan selanjutnya mengurani stress oksidatif.

\section{DAFTAR PUSTAKA}

Abramov, A. Y., Scorziello, A., \& Duchen, M. R. (2007). Three distinct mechanisms generate oxygen free radicals in neurons and contribute to cell death during anoxia and reoxygenation. Journal of Neuroscience.

Ardhie, A. M. (2011). Radikal Bebas dan Peran Antioksidan dalam Mencegah Penuaan. Medicinus, 24(1), 4-9.

Bag, A., \& Bag, N. (2008). Target sequence polymorphism of human manganese superoxide dismutase gene and its association with cancer risk: A review. Cancer Epidemiology Biomarkers and Prevention.

Case, A. (2017). On the Origin of Superoxide Dismutase: An Evolutionary Perspective of Superoxide-Mediated Redox Signaling. Antioxidants, 6(4), 82.

Euis, R. Y. (2018). Pengantar Radikal Bebas dan Antioksidan. In Deepublish;Yogyakarta.

Fachir, H., \& Setiawan, B. (2005). Stres oksidatif dan nitrosatif pada berbagai faktor risiko stroke. Berkala IImu Kedokteran, 37, 9499.

Fahn, H. J., Wang, L. S., Kao, S. H., Chang, S. C., Huang, M. H., \& Wei, Y. H. (1998). Smoking-associated mitochondrial DNA mutations and lipid peroxidation in human lung tissues. American Journal of Respiratory Cell and Molecular Biology.

Harju, T., Kaarteenaho-Wiik, R., Sirviö, R., Pääkkö, P., Crapo, J. D., Oury,
T. D., ... Kinnula, V. L. (2004). Manganese superoxide dismutase is increased in the airways of smokers' lungs. European Respiratory Journal.

Izyumov, D. S., Domnina, L. V., Nepryakhina, O. K., Avetisyan, A. V., Golyshev, S. A., Ivanova, O. Y., ... Chernyak, B. V. (2010). Mitochondria as source of reactive oxygen species under oxidative stress. Study with novel mitochondria-targeted

antioxidants - The "SkulachevIon" derivatives. Biochemistry (Moscow).

Kim, J., Mizokami, A., Shin, M., Izumi, K., Konaka, H., Kadono, Y., ... Namiki, M. (2014). SOD3 acts as a tumor suppressor in PC-3 prostate cancer cells via hydrogen peroxide accumulation.

Anticancer Research.

Kim, S. H., Kim, S. H., Lee, J. H., Lee, B. H., Yoon, H. J., Shin, D. H., ... Jee, Y. K. (2014). Superoxide dismutase gene (SOD1, SOD2, and SOD3) polymorphisms and antituberculosis drug-induced hepatitis. Allergy, Asthma and Immunology Research. https://doi.org/10.4168/aair.2015. 7.1 .88

Krajcovicova-Kudlackova, Dušinská, M., Valachovičová, Blažíček, M., Pauková, M., V., P., ... Pauková, V. (2006). Products of DNA, protein and lipid oxidative damage in relation to vitamin $\mathrm{C}$ plasma concentration. Research, 55, 227-231.

Landis, G. N., \& Tower, J. (2005). Corrigendum to "Superoxide dismutase evolution and life span regulation." Mechanisms of Ageing and Development, 126(8), 907908.

Lobo, V., Patil, A., Phatak, A., \& Chandra, N. (2010). Free radicals, antioxidants and functional foods: Impact on human health. Pharmacognosy Reviews.

Masaki, H. (2010). Role of antioxidants in the skin: Anti-aging effects. Journal of Dermatological Science.

Phaniendra, A., Jestadi, D. B., \& 
Periyasamy, L. (2015). Free Radicals: Properties, Sources, Targets, and Their Implication in Various Diseases. Indian Journal of Clinical Biochemistry, Vol. 30.

Pialoux, V., Hanly, P. J., Foster, G. E., Brugniaux, J. V., Beaudin, A. E., Hartmann, S. E., ... Poulin, M. J. (2009). Effects of exposure to intermittent hypoxia on oxidative stress and acute hypoxic ventilatory response in humans. American Journal of Respiratory and Critical Care Medicine.

Robak, J., \& Gryglewski, R. J. (1988). Flavonoids are scavengers of superoxide anions. Biochemical Pharmacology.

Tan, B. L., Norhaizan, M. E., Liew, W. P. P., \& Rahman, H. S. (2018). Antioxidant and oxidative stress: A mutual interplay in age-related diseases. Frontiers in Pharmacology.

Tsang, C. K. wa., Liu, Y., Thomas, J., Zhang, Y., \& Zheng, X. F. S. (2014). Superoxide dismutase 1 acts as a nuclear transcription factor to regulate oxidative stress resistance.

Nature Communications.

https://doi.org/10.1038/ncomms4 446

Werdhasari, A. (2014). Peran Antioksidan Bagi Kesehatan. Indonesian Journal of Biotechnology Medicine, 3, 59-68.

Widayati, E. (2012). Oxidasi Biologi, Radikal Bebas, dan Antioxidant. Majalah IImiah Sultan Agung, 50(128), 26-32.

Winarsi, H., Wijayanti, S. P. M., \& Purwanto, A. (2012). Aktivitas Enzim Superoksida Dismutase, Katalase, dan Glutation Peroksidase Wanita Penderita Sindrom Metabolik. Majalah Kedokteran Bandung.

Winarsih. (2007). Antioksidan Alami dan Radikal Bebas. Yogyakarta: Kanisius.

Younus, H. (2018). Therapeutic potentials of superoxide dismutase. International Journal of Health Sciences, 12(3), 88-93.

Yuan, G., Adhikary, G., McCormick, A.
A., Holcroft, J. J., Kumar, G. K., \& Prabhakar, N. R. (2004). Role of oxidative stress in intermittent hypoxia-induced immediate early gene activation in rat PC12 cells. Journal of Physiology.

Zainuri, M., \& Wanandi, S. I. (2012). AKTIVITAS SPESIFIK MANGANESE SUPEROXIDE DISMUTASE (MnSOD) DAN KATALASE PADA HATI TIKUS YANG DIINDUKSI HIPOKSIA SISTEMIK: HUBUNGANNYA DENGAN KERUSAKAN OKSIDATIF. Media of Health Research and Development, 22(2 Jun), 87-92.

Zelko, I. N., Mariani, T. J., \& Folz, R. J. (2002). Superoxide dismutase multigene family: A comparison of the CuZn-SOD (SOD1), Mn-SOD (SOD2), and EC-SOD (SOD3) gene structures, evolution, and expression. Free Radical Biology and Medicine.

Zhang, X., Ng, W. L., Wang, P., Tian, L. L., Werner, E., Wang, H., ... Wang, Y. (2012). MicroRNA-21 modulates the levels of reactive oxygen species by targeting SOD3 and TNFa. Cancer Research. https://doi.org/10.1158/00085472.CAN-12-0639 